\title{
Peran anggota badan legislatif perempuan dalam perspektif gender (study perilaku politik 2 anggota DPRD DKI Jakarta Fraksi Partai Solidaritas Indonesia)
} lqbal Syafrudin ${ }^{\text {a, }}{ }^{*}$

${ }^{a}$ Pendidikan Pancasila dan Kewarganegaraan, Universitas Negeri Jakarta, Indonesia

${ }^{1}$ syafrudin@unj.ac.id*

*korespondensi penulis

\begin{abstract}
ABSTRAK
Penelitian ini fokus mengkaji mengenai peran anggota legislatif perempuan di DPRD DKI Jakarta Fraksi PSI dalam mewujudkan kesetaraan gender di Komisi yang mereka duduki. Anggota badan legislatif perempuan yang selama ini dipandang sebagai wakil perempuan yang diharapkan bisa berperan maksimal dalam legislasi, pengawasan, dan penganggaran baik di DPRD Kabupaten/Kota atau DPR RI terlihat masih belum maksimal dalam menjalankan perannya. Peran maksimal anggota legislatif perempuan akan terlihat dari perannya didalam rapat yang didominasi oleh anggota legislatif yang didominasi oleh anggota laki-laki. Fenomena yang tergambar akan terlihat bagaimana peran anggota legislatif perempuan dalam menjalankan tugasnya di DPRD DKI Jakarta dalam mewujudkan kesetaraan gender. Penelitian ini akan memfokuskan kepada 2 Anggota Perempuan Anggota DPRD DKI Jakarta Fraksi PSI melihat perilaku politik keduanya ditengah dominasi laki-laki. Sehingga disini peneliti ingin melihat sosok perempuan dalam legislative bagaimana perannya diantara anggota laki-laki. Metode yang digunakan dalam penelitian ini adalah pendekatan kualitatif. Pendekatan kualitatif dipilih karena penelitian ini bersifat mengumpulkan dan menganalisis data berupa katakata (lisan maupun tulisan) dan perbuatan- perbuatan manusia dalam hal ini 2 anggota legislative perempuan di DPRD DKI Jakarta, Selanjutnya menggunakan content analysis untuk melihat data hasil wawancaranya untuk kita analisa. Hasil penelitian ini bahwa gender dan perilaku politik secara regulasi dan aturan tidak ada masalah dan bahkan lebih menguntungkan perempuan tapi memang dalam praktek dilapangan disaat kampanye dan bahkan ketika terpilitih disitu letak kesulitian dan tantangannya.
\end{abstract}

\section{ABSTRACT}

This research focuses on examining the role of women legislative members in the DPRD DKI Jakarta PSI faction in realizing gender equality in the Commission they occupy. Women members of the legislative body who have been seen as women's representatives who are expected to play a maximum role in legislation, supervision and budgeting, both in the Regency / City DPRD or DPR RI, seem to have not been maximal in carrying out their roles. The maximum role of women legislators can be seen from their roles in meetings which are dominated by legislative members who are dominated by male members. The illustrated phenomenon will be seen how the role of women legislative members in carrying out their duties at the DKI Jakarta DPRD in realizing gender equality. This research will focus on 2 female members of DPRD DKI Jakarta, the PSI faction to see the political behavior of both of them in the midst of male domination. So that here the researcher wants to see the figure of women in the legislature how their roles are among male members. The method used in this research is a qualitative approach. The qualitative approach was chosen because this research collects and analyzes data in the form of words (oral and written) and human actions, in this case 2 women legislative members in the DKI Jakarta DPRD. Furthermore, they use content analysis to see the interview data for us to analyze. The results of this study show that gender and political behavior in terms of regulations and rules have no problem and are even more beneficial for women, but it is in practice in the field during campaigns and even when torn there are difficulties and challenges.
Sejarah Artikel

Diterima: 5 Januari 2021

Disetujui: 10 Maret 2021

Kata kunci:

Perempuan

Gender

Perilaku Politik

DPRD DKI Jakarta

PSI

Article's Information:

Received: 5 January 2020

Accepted: 10 March 2021

Keywords:

Women

Gender

Political Behavior

DPRD DKI Jakarta

PSI

\section{Pendahuluan}

Artikel ini bertujuan Mengetahui perilaku politik 2 anggota legislatif perempuan F-PSI dalam mewujudkan kesetaraan gender, Melihat peranan perempuan dalam proses sebuah kebijakan, Penelitian ini dapat berguna sebagai refrensi atau bahan bacaan untuk penelitian yang sejenis dalam 
pengembangan ilmu pengetahuan yang akan datang. Indonesia merupakan salah satu negara yang tingkat keterwakilan perempuan di lembaga legislatifnya masih rendah walaupun aturannya sudah mengalami peningkatan sebesar 30\%. Rendahnya keterwakilan perempuan serta peranannya di lembaga legislatif ini disebabkan oleh banyak faktor seperti faktor budaya, lemahnya peraturan tentang keterwakilan perempuan, rendahnya political will dari pemerintah dan partai politik, sistem pemilu, gender dan faktor masyarakat yang masih kurang yakin dengan peran perempuan dalam ranah politik, serta masih banyak lagi yang lainnya. Padahal dengan perubahan zaman peran perempuan sudah banyak yang hampir sama dengan laki-laki.

Undang-undang No 7 Tahun 2017 Tentang Pemilihan Umum memerintahkan agar Penyelenggara Pemilu, Partai Politik dan Kandidat untuk memperhatikan keterwakilan perempuan paling sedikit 30 persen. Lebih lanjut dijelaskan, dalam Undang-undang Nomor 15 Tahun 2011 tentang Penyelenggara Pemilu. UU tersebut tidak jauh berbeda dengan UU No 10 Tahun 2008 untuk soal kuota perempuan. Kuota 30\% yang merupakan sebuah awal dari keikutsertaan perempuan dalam politik Indonesia kemudian mewarnai proses politik yang berjalan dimana dengan kuota tersebut perempuan kemudian dilibatkan dalam dunia politik. Tidak hanya upaya tetap menegakkan keterwakilan perempuan dalam sistem politik Indonesia sudah ada dan bahkan cenderung sudah mewajibkannya, maka perempuan juga harus ikut serta dalam keterlibatan kebijakan lainnya dalam sistem yang ada baik itu tingkat pusat hingga ke tingkat daerah serta perempuan juga harus ikut berperan andil dalam partai politik yang ada demi untuk menjaga keberlangsungan proses perjuangan mereka dalam menuntut kesetaraan hak. Selain itu mereka harus menunjukkan peran mereka sebagai legislator yang handal dan jika bias lebih baik dari laki-laki.

Adapun Anggota Perempuan DPRD DKI Jakarta dari PSI 2019-2024 berjumlah 8 orang, dan Anggota Laki-laki berjumlah 6 orang dan 2 orang perempuan. Berikut nama anggota DPRD DKI Jakarta F-PSI :

\begin{tabular}{llll}
\hline No & Nama & Dapil & Komisi \\
\hline 1 & Idris Ahmad & Dapil I & Komisi E \\
2 & Anggara Wicitra Sastroamidjojo & Dapil 7 & Komisi E \\
3 & August Hamonangan & Dapil 8 & Komisi A \\
4 & William Aditya Sarana & Dapil 9 & Komisi A \\
5 & Anthony Winza Probowo & Dapil 2 & Komisi C \\
6 & Justin Adrian & Dapil 5 & Komisi E \\
7 & Eneng Malianasari & Dapil 10 & Komisi B \\
8 & Viani Limardi & Dapil 3 & Komisi D \\
\hline
\end{tabular}

Dalam penelitiannya, Irma Latifah Sihite meneliti tentang faktor lemahnya peraturan keterwakilan perempuan di Indonesia yang berdampak pada rendahnya keterwakilan perempuan di lembaga legislatif di Indonesia. Dari hasil penelitiannya tercatat bahwa lemahnya peraturan keterwakilan perempuan disebabkan karena pertama, belum adanya kemauan politik dari partai politik dan pemerintah dalam upaya peningkatan keterwakilan perempuan di lembaga legislatif, kedua, faktor kultural dan struktural yang selalu membuat perempuan terdiskriminasi di Indonesia (Sihite, 2011).

Dalam Jurnal UIN Walisongo Semarang yang ditulis oleh Ulfatun Hasanah dan Najahan Musyafak yang berjudul Keterlibatan Perempuan Dalam Pembangunan. Dalam konteks pembangunan kadang kala gender selalu dikesampingkan Akibatnya adalah gender mengalami eksklusi sosial yaitu proses yang menghalangi atau menghambat individu dan keluarga, kelompok dan kampung dari sumber daya yang dibutuhkan untuk berpartisipasi dalam kegiatan sosial, ekonomi dan 
politik di dalam masyarakat dengan utuh. Maka terciptalah ketidaksetaraan gender atau ketidakadilan gender dalam pembangunan.

Perbedaan tulisan ini terletak pada substansi peran 2 anggota DPRD DKI F-PSI dalam perilaku politiknya dalam kesetaraan gender sehingga terlihat bagaimana kinerja dan lingkungan terhadap kesetaraan dalam kinerja di DPRD terjadi atau tidak.

\section{Metode}

Dalam penyusunan artikel ini data-data dikumpulkan melalui p pendekatan kualitiatif dengan jenis penelitian studi kasus. Jenis penelitian studi kasus biasanya digunakan untuk meneliti fenomena individual, organisasi, sosial, dan politik. Penelitian studi kasus dapat membantu peneliti memahami fenomena secara holistik dan bermakna (Robert. K. Yin, 2004).

Pendekatan kualitatif dan jenis penelitian studi kasus digunakan karena metode ini dapat membantu peneliti memahami fenomena politik yang menjadi masalah penelitian ini. Metode ini mengharuskan peneliti memberikan latar belakang historis dari fenomena tersebut, sehingga fenomena politik tersebut dapat dijelaskan sebab terjadinya. Metode kualitatif mengharuskan peneliti menggali lebih dalam data-data yang berasal dari informan dengan wawancara mendalam, sehingga permasalahan yang diteliti dapat diketahui dengan lebih rinci.

Proses penelitian kualititaf ini melibatkan berbagai upaya penting seperti mengajukan pertanyaan mendalam dan prosedur-prosedur, mengumpulkan data yang spesifik dari partisipan yang teridentifikasi, menganalisa data secara induktif, serta menafsirkan makna data. Laporan akhir untuk penelitian model kualititaf memiliki struktur yang fleksibel karena harus mampu menerjemahkan kompleksitas suatu persoalan.

\section{Hasil dan Pembahasan}

Selama ini ada anggapan bahwa dunia politik identik dengan dunia laki-laki. Anggapan ini muncul akibat adanya "image" yang tidak sepenuhnya tepat tentang kehidupan politik; yaitu bahwa politik itu kotor, keras, penuh intrik, dan semacamnya, yang diidentik-kan dengan karakteristik lakilaki. Akibatnya, jumlah perempuan yang terjun di dunia politik kecil, termasuk di negara-negara yang tingkat demokrasinya dan persamaan hak asasinya cukup tinggi. Selain itu, kesan semacam itu muncul karena secara historis, khususnya pada tahap awal perkembangan manusia, kaum pria selalu identik dengan aktivitas kerja di luar rumah, sementara perempuan bertugas menyiapkan kebutuhan keluarga di dalam rumah seperti memasak, mengasuh anak, dan melayani suami. Tentu ini juga terjadi kerap bahwa peranan politisi perempua kadang tidak diperhitungakan atau dihiraukan oleh politisi laki-laki. Padahal dalam berpolitik kedudukan semuanya sama dengan perannya masingmasing.

Kedudukan dan peranan perempuan di Indonesia telah muncul sejak lama. Begitu banyak tercatat sejumlah tokoh perempuan yang turut memberikan andil dalam aktivitas politik, dengan perjuangan fisik melawan penjajah, serta berbagai bentuk perlawanan yang telah dilakukan untuk memperjuangkan hak-hak perempuan untuk memperoleh pendidikan, peluang kerja yang setara dengan pria, serta bentuk-bentuk kekerasan pada perempuan (Bakti, 2012:149).

Begitu banyak cara yang dilakukan oleh tokoh-tokoh perempuan, untuk memperjuangkan hakhaknya. Dan hal itu membuahkan hasil, yaitu telah membuka jalan bagi kaum perempuan untuk berkiprah dalam segala aspek kehidupan termasuk dunia politik. Berbagai bentuk perjuangan politik telah digeluti kaum perempuan, seperti parlemen, kabinet, partai politik, LSM, dan sebagainya. Mereka berpikir perempuan juga mempunyai kemampuan dan kekuasaan yang sama dengan lakilaki, yang juga bias digunakan untuk mempolitisir dan mengontrol kaum laki-laki, bisa memberikan suaraterbanyak, serta bisa dimanfaatkan demi kepentingan tertentu (Primariantari, 1998:41). 
Salah satu yang perlu diperhitungkan keberadaannya dalam dunia politik sekarang adalah kaum perempuan dimana selain merupakan pemberi suara terbanyak, perempuan juga sudah banyak yang terlibat langsung dalam partai politik misalnya sebagai pengurus partai, pengambil keputusan dan sebagai calon anggota legislatif (Caleg). Keterwakilan perempuan dalam politik, terutama di lembaga perwakilan rakyat (DPR/DPRD), bukan tanpa alasan yang mendasar. Ada beberapa hal yang membuat pemenuhan kuota $30 \%$ bagi keterwakilan perempuan dalam politik dianggap sebagai sesuatu yang penting. Beberapa di antaranya adalah tanggung jawab dan kepekaan akan isu-isu kebijakan publik, terutama yang terkait dengan perempuan dan anak, lingkungan sosial, moral yang baik, kemampuan perempuan melakukan pekerjaan multitasking, dan pengelolaan waktu.

Bagi Sis Viyani ketika diwawancara tentang rintangan dan tantangannya sebagai anggota dewan, ibu, dan isteri seperti apa, lalu Sis Viyani menjawab dengan serius dan santai. "Bagi saya untuk sampai pada proses hari ini sangat panjang dan tidaklah mudah untuk menjadi kursi DPRD, Bahkan ketika jadi Anggota DPRD pun ia harus bisa membagi waktu untuk menjadi seorang isteri, ibu, dan wakil rakyat. Tentu perjuangan yang panjang hingga terpilih apalagi saya seorang perempuan tentu itu menjadi tanggung jawab saya untuk bersemangat dan totalitas ketika mengunjungi masyarakat".

Banyak hal yang terjadi dan terdapat di Indonesia yang memutlakan keterwakilan para perempuannya yang memadai dalam kuantitas dan kualitas di lembaga-lembaga negara dan sektorsektor publik lainnya untuk menciptakan perubahan-perubahan mendasar dalam kehidupan bernegara dan bermasyarakat. Peluang-peluang politik telah dibuat agar perempuan turut berpartisipasi dalam politik namun ketika perempuan telah turut andil berpartisipasi masih banyak juga rintangan dan tantangan yang ditemukan.

Adapun petikan jawaban kedua anggota dewan tersebut perihal soal posisi diri mereka seorang perempuan ditengah para pria ketika rapat Fraksi maupun Komisi ketika mengambil keputusan atau musyawarah yang tidak jauh berbeda sebagai berikut; ; Selama awal sekali dilantik menjadi dewan saya belum mengalami yang namanya ketidaksetaraan karna sebagai wanita ketika saat sedang rapat ataupun musyawarah dan tidak mengalami pelecehan dalam arti disepelekan oleh anggota dewan lainnya karna saya sebagai anggota DPRD dari partai baru, ujar Sis Mili dan Sis Viyani".

Perilaku politik pada umumnya ditentukan oleh 2 faktor yaitu Faktor internal dan eksternal. Internal terdiri dari individu itu sendiri seperti idealisme.Tingkat kecerdasan, kehendak hati dan Eksternal (kondisi lingkungan) seperti kehidupan beragama, sosial, politik, ekonomi, dan sebagainya yang mengelilinginya. Perilaku politik meliputi tanggapan internal seperti persepsi, sikap, orientasi dan keyakinan serta tindakan-tindakan nyata seperti pemberian suara, protes, lobi dan sebagainya.

Apa yang dilakukan Sis Mili atau Eneng Malianasari ketika saat ditanya soal perilaku politik yang berkenaan dengan kegiatan dirnya sebagai anggota dewan dengan latar belakang pendidikannya serta sebagai aktifis sekaligus seniman sebagai berikut; "Dengan latar belakang saya sebagai seorang aktifis ketika menjadi mahasiswa dibandung dan ketika di aktif dikegiatan NGO bidang perempuan dan ikut dibidang seni jalanan di Jakarta. Sudah banyak hal yang saya lakukan sesuai dengan bidang saya, misalkan untuk di komisi B yang membidangi perindustrian dan energi, kelautan dan pertanian, koperasi, usaha mikro, kecil dan menengah dan perdagangan, pariwisata dan kebudayaan, penanaman modal dan promosi, ketahanan pangan, perhubungan, perikanan, peternakan, ketenagakerjaan dan transmigrasi, pemberdayaan aset/kekayaan daerah, dan perusahaan daerah. Tentu saya mengawasi dari setiap program kerja pemerintah DKI Jakarta, dan memperjuangankan dengan program program yang menguntungkan masyarakat dan tentu untuk kalangan seniman yang dimana memang saya sangat konses pada bidang seni"

Menurut Ramlan Surbakti (2010:167) perilaku politik yaitu kegiatan yang berkaitan dengan proses pembuatan keputusan politik. Perilaku politik merupakan salah unsur atau aspek perilaku secara umum, terdapat perilaku-perilaku lain seperti perilaku organisasi, perilaku budaya, perilaku konsumen/ekonomi, perilaku keagamaan dan lain sebagainya. Menurut (Sobolim, 2013) Perilaku politik atau (Politic Behaviour) adalah perilaku yang dilakukan oleh insan/individu atau kelompok guna memenuhi hak dan kewajibannya sebagai insan politik. 
Dalam wawancara dengan Sis Viyani perihal apa saja yang berkaitan dengan perilaku politik sebagai perempuan di DPRD dan tantangannya sebagai perempuan dikala pria mendominasi. "Banyak dalam hal perumusan kebijakan perda dll, tentu bagi saya tantanganya adalah bagaimana menunjukan bahwa dirinya sebagai perempuan juga bisa berkontribusi baik ide gagasan dan dilapangan ketika melakukan kunjungan ke dapil sebagai pertanggungjawaban saya kepada pemilih saya".

Menurut Elly M. Setiadi dan Usman Kolip peilaku politik adalah kegiatan aktivitas manusia yang berhubungan dengan distribusi kekuasaan dan kewenangan di dalam suatu negara, juga aktivitas yang berupa aksi dan reaksi yang berhubungan dengan kebijakan publik sebagai produk dari proses politik dalam struktur politik disuatu negara.

Saat ditanya soal ide gagasannya sendiri dengan kebijakan DPP baik Sis Mili ataupun Sis Viyani apakah ada tantangan dan halangan tersendir, keduanya memiliki jawaban berbeda tapi pointnya hampir sama. "Mekanisme dalam pengambilan keputusan biasanya dilihat efek baik secara untuk masyarakat dan pastinya secara politik juga. Misalkan jika kita ada satu sikap Fraksi maka kita akan bermusyawarah bersama seluruh anggota dewan PSI dan kita berdiskusi dan menyikapi masingmasing bersuara. Jika berbeda maka terus hingga menemukan titik temu jika tidak ketemu maka kita ambil vote dan harus menerima. Tapi ada juga jika memang ada intruksi DPP maka kita harus menyikapi dengan dipikirkan kembali dan dibahas baru bersikap sesuai intruksi DPP. Ujar Sis Mili".

Menurut Sudijono perilaku politik yaitu berupa perilaku lembaga-lembaga politik dan dapat berupa perilaku individu. Perilaku politik yang disebut pertama adalah dijalankan oleh lembagalembaga politik sesuai dengan tugas dan wewenang yang ada padanya, sedangkan yang disebut terakhir perilaku politik adalah yang dijalankan oleh tiap-tiap individu sebagai peran serta didalam kehidupan politik (Sudijono Sastroatmodjo 1995: 67).

\section{Simpulan}

Berdasarkan hasil penelitian dan pembahasan maka dapat disimpulkan bahwa gender dan perilaku politik secara regulasi dan aturan tidak ada masalah dan bahkan lebih menguntungkan perempuan tapi memang dalam praktek dilapangan disaat kampanye dan bahkan ketika terpilitih disitu letak kesulitian dan tantangannya. Tentu sesuai apa yang dialami oleh kedua anggota DPRD DKI Jakarta F-PSI. Untuk di Fraksi PSI terlihat dinamika gender dan perilaku politik sangat dinamis dan cenderung egaliter saat pengambilan sikap atau keputusan Fraksi.

Jika di Komisi cenderung keras tapi tidak mendiskritkan perempuan dan itu hal biasa jika berdebat dalam forum dalam pengambilan keputusan. Saat di Insturksi atau pun disuruh selesai oleh pimpinan sidang. Sesuai dengan wawancara dengan Sis Mili dan Viyani.

Yang menarik adalah ketika adanya inturksi DPP yang harus disikapi oleh Fraksi dan mungkin semua dinamika partai sama. Dimana sikap partai mengikat dan harus dipatuhi oleh anggota. Baik Sis Mili dan Sis Viyani menceritakan hal yang sama soal intruksi DPP atau kebijakan politik DPP yang harus dipatuhi oleh Anggota Fraksi.

\section{Referensi}

Fakih, M. (1999). Analisis gender \& transformasi sosial. Yogyakarta: Pustaka Pelajar.

Murniati, A.N.P. (2004). Getar gender "perempuan Indonesia dalam perspektif agama, budaya dan keluarga" (second edition. ed). Magelang: INDONESIATERA.

Nurcahaya, T.A. (2004). Kembalikan hak perempuan. Yogyakarta: Pustaka Timur.

Pelajar, P. et. all. (1998) Perempuan dan politik tubuh fantastis. Yogyakarta: Pustaka Pelajar 
Putra, F. (2004). Paradigma kritis dalam studi kebijakan publik. Yogyakarta: Pustaka Pelajar

Sihite, I. L. (2011). Penerapan affirmative action sebagai upaya peningkatan keterwakilan perempuan dalam parlemen di Indonesia. Jakarta: Universitas Indonesia.

Soeseno, N. (2014). Perempuan politisi dalam partai politik pemilu 2014: keterwakilan deskriptif vs substantif. Jurnal Perempuan "Untuk Pencerahan dan Kesetaraan". 19 (2).

Squires, J. (1999). Gender in political theory. Cambridge: The Polity Press.

Surbakti, R. (1999). Memahami ilmu politik. Jakarta: Grasindo

Susilatuti, D. H. (2013). Kepemimpinan perempuan: perubahan paradigma dari politik gagasan ke politik kehadiran. Jurnal Perempuan. 18.

Undang-undang No 7 Tahun 2017

Yin, R. K. (2004). Metodologi penelitian studi kasus. Jakarta: Raja Grafindo Persada 